\title{
Performance Analysis of Spark Ignition Engine Fueled with Methanol/Petrol Fuel Blends
}

\author{
V. Jose Ananth Vino*, R. Solomon and S. Sreenath \\ Department of Mechanical Engineering, Bharath Institute of Science and Technology, \\ Bharath University, Chennai, Tamil Nadu, India; ananthvinovj258@gmail.com; \\ solomon053@gmail.com; sreenath.unicorn@gmail.com
}

\begin{abstract}
Much research is going on to find a suitable alternate fuel, to reduce the exhaust emission level and to increase the power output of an engine. An effort has been made in this project to fulfill the above needs by using the engine with petrol alcohol fuel blends. It has been observed that as the percentage of alcohol increases, exhaust emission levels of carbon monoxide and hydrocarbons decrease drastically. However, power output starts to decrease. By making engine modification such as increasing the engine compression ratio and advancing the ignition timing, almost $12.5 \%$ increase in the power output has been achieved in this project.
\end{abstract}

Keywords: Compression Ratio, Ignition Timing, Methonal, Clearance Volume, Power.

\section{Introduction}

Rising gas in prices is having dramatic negative effects on many parts of the world. Since 1993, China became a net petroleum import country and increasing quickly. In 2005, more than 140 million tons were imported. China is the second biggest country of petroleum importing, just behind the US. Currently, there are about 31 million automobiles in use, but the running time and fuel consumption are greater. Around $35 \%$ of the total 320 million ton petroleum was consumed as fuel by automobiles, where gasoline consumption is some 70 million tons (26 million US gallons). By 2010, the consumption reached 200 tons. To deal with the higher and higher petroleum price and to keep the fast development of automobile industry, alternative fuels are regarded highly. For spark ignition (SI) engine powered vehicles, alcohols like methanol and ethanol, are tested and demonstrated in the world. There were 5 cities taking part in the first stage demonstration of E10 (10\% ethanol in volume and 90\% gasoline in volume) fuel blends since 2002, and more cities and provinces joined in the program in 2004 accordingly.

Methanol as a fuel has been pursued globally for over forty years. Extensive research on methanol as a motor fuel was done in the 1970s and 1980s by Texas A\&M University. The Oxygenated Fuels Association also sponsored research on methanol as a fuel in the 1980s. However, today, the only major uses for methanol as a fuel are in race cars and selected provinces in China.

Alcohol fuels like Methanol are perhaps the most "transparent" alternative fuels to the user, i.e., they are the least distinguishable from gasoline in mode of purchase and use, which should ease acceptance. The fuel system of a car or truck only needs to be slightly changed, and recently automakers have been offering Methanol run vehicles at no extra cost over their gasoline counterparts. And perhaps best of all, modern Methanol run vehicles are flex-fuel vehicles, which means that any mixture of Methanol and gasoline in the fuel tank can be used by the engine; a fuel-composition sensor tells the engine computer what percentage of methanol is in the fuel, and it adjusts the injectors and ignition accordingly. Thus a Methanol vehicle is a gasoline vehicle if Methanol is not available, but methanol can be added whenever available and two different fuel systems are not needed.

Methanol is more corrosive than gasoline (though it is less toxic and not carcinogenic); this is why an automaker needs to change some of the materials in the fuel-handling

\footnotetext{
* Corresponding author:

V. Jose Ananth Vino (ananthvinovj258@gmail.com)
} 
systems of both the vehicle and the refueling station to materials that can withstand attack by the fuel. Special oil additives are necessary in order to protect the engine. Also, because the mixture of air to fuel is much richer than gasoline, there is more liquid fuel available to wash oil off of cylinder walls during a cold start. Some early methanol users experienced durability problems, but development work has been making steady progress. Some manufacturers recommend mixing additional gasoline with Methanol in very cold weather.

- Octane rating of methanol is 115

- Calorific value of methanol :

Lower Heating value $=643$ to $652 \mathrm{KJ} / \mathrm{mole}$

Higher Heating value $=726$ to $733 \mathrm{KJ} / \mathrm{mole}$

Methanol, also known as methyl alcohol, wood alcohol, wood naphtha, or wood spirits has the chemical formula $\mathrm{CH} 3 \mathrm{OH}$ and is the simplest alcohol in existence. Often abbreviated $\mathrm{MeOH}$, methanol is a light, volatile, colourless, flammable liquid with a distinctive odour similar to, but slightly sweeter than ethanol.

Methanol is an alternate fuel for internal combustion engines, either when blended with gasoline or used directly. However, use of methanol today as a gasoline blend or directly as a fuel is minimal. The uses are primarily for fuel in racing cars and fuel in select provinces in China.

China currently blends approximately 87,000 barrels of methanol daily, or about 4 million metric tons per year into gasoline. This represents approximately $4.5 \%$ of the gasoline production in China. China is the only country that uses large volumes of methanol as a fuel blend stock.

In the United States, there is effectively no methanol blended in fuels other than specific applications for race cars. Methanol is banned as a fuel blend stock in many nations The Environmental Protection Agency (EPA) permits methanol use in other American states at concentrations up to $2.75 \%$, when accompanied by $2.75 \%$ co-solvent to facilitate miscibility.

In this paper, an effort has been made to analyse I.C. engine with petrol alcohol fuel blends. It has been observed that as the percentage of alcohol increases, exhaust emission levels of carbon monoxide and hydrocarbons decrease drastically. However, power output starts to decrease $[1,4]$. By making engine modification such as increasing the engine compression ratio and advancing the ignition timing, almost $12.5 \%$ increase in the power output has been achieved in this project.

\section{Modifications on the Engine for Improved Performance}

\subsection{Engine Specification}

The engine used for the project was taken from a Kawasaki caliber. The essential specifications of the engine are listed below.

$\begin{array}{ll}\text { Bore Diameter } & =53 \mathrm{~mm} \\ \text { Stroke Length } & =50.6 \mathrm{~mm} \\ \text { Compression Ratio } & =9.9: 1\end{array}$

Research shows that there is a decrease in power output when methanol is blended with petrol. To overcome this problem, the compression ratio and the ignition timing can be modified.

\subsection{Compression Ratio Modification}

\section{a. Unaltered Engine Dimension}

$\begin{aligned} \text { Bore Diameter } & =53 \mathrm{~mm} \\ \text { Stroke Length } & =5.3 \mathrm{~cm} \\ & =50.6 \mathrm{~mm} \\ \text { Swept Volume }\left(\mathrm{V}_{\mathrm{s}}\right) & =\frac{\pi}{4} \mathrm{~d}^{2} \mathrm{~cm} \\ & =\frac{\pi}{4}(5.3)^{2 *} 5.06 \\ \mathrm{~V}_{\mathrm{s}} & =111.63 \mathrm{cc}\end{aligned}$

b. Existing Compression Ratio

$\begin{array}{lll}\mathrm{R}_{\mathrm{C}} & = & 9.9: 1 \\ \mathrm{R}_{\mathrm{C}} & = & \frac{V_{s}+V_{c}}{V_{c}} \\ 9.9 & = & \frac{11.63+V_{c}}{V_{c}} \\ 9.9 \mathrm{~V}_{\mathrm{C}}-\mathrm{V}_{\mathrm{C}} & = & 11.63 \\ \mathrm{~V}_{\mathrm{C}}[9.9-1] & = & 11.63 \\ \mathrm{~V}_{\mathrm{C}} & = & \frac{11.63}{8.9} \\ \mathrm{~V}_{\mathrm{C}} & = & 12.54 \mathrm{~cm}^{3}\end{array}$

\section{c. Modification to Obtain New Compression Ratio}

After removing $0.4 \mathrm{~mm}$ of surface material from the cylinder head,

New clearance volume $\left(\mathrm{V}_{\mathrm{c}}{ }^{1}\right)=12.54-\frac{\pi}{4} * 5.3^{2 *} 0.04$

$$
\mathrm{V}_{\mathrm{c}}{ }^{1}=11.7 \mathrm{~cm}^{3}
$$

Modified Compression Ratio $=\frac{V_{S}+V_{C}^{1}}{V_{C}^{1}}$ 


\section{$=\frac{11.63+11.7}{11.7}$}

Modified Compression Ratio $\mathbf{R}_{\mathrm{c}}{ }^{1}=$

10.54:1

The ignition timing of conventional engine are usually around $20^{\circ}$ before reaching TDC. After modification, the ignition takes place at an angle of $29^{\circ}$ from the TDC.

\section{Performance Analysis of Experimental Engine}

\subsection{Formula Derivation to Find the Brake}

\section{Power}

Circumference of the brake drum

$$
\begin{aligned}
& =110.5 \mathrm{~cm} \\
& =110.5 \\
& =\frac{110.5}{\pi} \\
& =35.173 \mathrm{~cm} \\
& =0.351 \mathrm{~m} \\
& =\frac{D}{2} \\
& =0.175 \mathbf{m} \\
& =\frac{\pi 2 N T}{60}
\end{aligned}
$$$$
\pi \mathrm{D}
$$$$
\mathrm{D}
$$

Radius of brake drum $\mathbf{r}$

Engine Brake Power (P)

Where,

' $\mathrm{P}$ ' is the power in watts

' $\mathrm{T}$ ' is torque in $\mathrm{Nm}$

\section{Engine Brake Power (P)}

$$
=\frac{\pi 2 N * * r}{60}
$$

(1)

\subsection{Power Performance before Engine

\begin{tabular}{|c|c|c|c|c|c|c|c|c|}
\hline \multirow[t]{2}{*}{ Sno } & \multirow[t]{2}{*}{ Throttle Position } & \multicolumn{3}{|c|}{ Load In Kgf } & \multirow{2}{*}{$\begin{array}{l}\text { Load In } \\
\text { Newton }\end{array}$} & \multirow{2}{*}{$\begin{array}{l}\text { Break } \\
\text { Drum } \\
\text { Speed }\end{array}$} & \multirow{2}{*}{$\begin{array}{c}\text { Engine } \\
\text { Speed In } \\
\text { RPM }\end{array}$} & \multirow{2}{*}{$\begin{array}{c}\text { Brake } \\
\text { Power In } \\
\text { Kw }\end{array}$} \\
\hline & & $\mathrm{S}_{1}$ & $\mathrm{~S}_{2}$ & $\mathrm{~S}_{1}-\mathrm{S}_{2}$ & & & & \\
\hline 1 & Idling & 0 & 0 & 0 & 0 & 260 & 660 & - \\
\hline 2 & 1/4 Throttle & 25 & 5 & 20 & 200 & 455 & 1500 & 1.66 \\
\hline 3 & 1/2 Throttle & 24 & 6 & 18 & 180 & 909 & 3000 & 3.1 \\
\hline 4 & $3 / 4$ Throttle & 24 & 8 & 16 & 160 & 1364 & 4500 & 4.02 \\
\hline 5 & Full Throttle & 16 & 15 & 11 & 110 & 1818 & 6000 & 3.81 \\
\hline
\end{tabular} Modification}

Using Eqn. (1), the engine brake power was found out for different ratios of the fuel blends before modifications was done $[2,3,5]$. The findings of all the trials are tabulated in Table 1, 2 and 3 respectively.

\section{CAse 1}

\section{Fuel Used: Petrol}

Table 1. Power performance for petrol

\section{CASE 2}

Fuel Used: $90 \%$ Petrol + 10\% Methanol

Table 2. Power performance for $90 \%$ Petrol $+10 \%$

Methanol

\begin{tabular}{|l|l|l|l|l|l|l|l|l|}
\hline Sno & $\begin{array}{l}\text { Throttle } \\
\text { Position }\end{array}$ & \multicolumn{2}{|l|}{ Load In Kgf } & $\begin{array}{l}\text { Load In } \\
\text { Newton }\end{array}$ & $\begin{array}{l}\text { Break } \\
\text { Drum } \\
\text { Speed }\end{array}$ & $\begin{array}{l}\text { Engine } \\
\text { Speed In } \\
\text { RPM }\end{array}$ & $\begin{array}{l}\text { Brake } \\
\text { Power In } \\
\text { Kw }\end{array}$ \\
\hline & & $\mathrm{S}_{1}$ & $\mathrm{~S}_{2}$ & $\mathrm{~S}_{1}-\mathrm{S}_{2}$ & & & & \\
\hline 1 & Idling & 0 & 0 & 0 & 0 & 190 & 627 & - \\
\hline 2 & $1 / 4$ Throttle & 24 & 6 & 18 & 180 & 455 & 1500 & 1.5 \\
\hline 3 & $1 / 2$ Throttle & 22 & 5 & 17 & 170 & 909 & 3000 & 2.9 \\
\hline 4 & $3 / 4$ Throttle & 20 & 5 & 15 & 150 & 1364 & 4500 & 3.8 \\
\hline 5 & Full Throttle & 15.5 & 5 & 10.3 & 105 & 1818 & 6000 & 3.5 \\
\hline
\end{tabular}

\section{CASE 3}

Fuel Used: $80 \%$ Petrol $+20 \%$ Methanol

Table 3. Power performance for $80 \%$ Petrol $+20 \%$ Methanol

\begin{tabular}{|l|l|l|l|l|l|l|l|l|}
\hline Sno & $\begin{array}{l}\text { Throttle } \\
\text { Position }\end{array}$ & \multicolumn{3}{|l|}{ Load In Kgf } & $\begin{array}{l}\text { Load In } \\
\text { Newton }\end{array}$ & $\begin{array}{l}\text { Break } \\
\text { Drum } \\
\text { Speed }\end{array}$ & $\begin{array}{l}\text { Engine } \\
\text { Speed In } \\
\text { RPM }\end{array}$ & $\begin{array}{l}\text { Brake } \\
\text { Power In } \\
\text { Kw }\end{array}$ \\
\hline & & $S_{1}$ & $S_{2}$ & $S_{1}-S_{2}$ & & & & \\
\hline 1 & Idling & 0 & 0 & 0 & 0 & 175 & 578 & - \\
\hline 2 & $1 / 4$ Throttle & 2 & 6 & 17 & 170 & 455 & 1500 & 1.4 \\
\hline 3 & $1 / 2$ Throttle & 22 & 6 & 16 & 160 & 909 & 3000 & 2.7 \\
\hline 4 & $3 / 4$ Throttle & 20 & 5 & 15 & 150 & 1364 & 4500 & 3.7 \\
\hline 5 & Full Throttle & 15 & 5 & 10 & 100 & 1818 & 6000 & 3.25 \\
\hline
\end{tabular}

\subsection{Power Performance after Engine Modification}

Using Eqn. (1), the engine brake power was found out for different ratios of the fuel blends after modifications was done. The findings of all the trials are tabulated in Table 4 and 5 respectively.

\section{CASE 1}

Fuel Used: $90 \%$ Petrol + 10\% Methanol

Table 4. Power performance for $90 \%$ Petrol $+10 \%$ Methanol

\begin{tabular}{|l|l|l|l|l|l|l|l|l|}
\hline Sno & $\begin{array}{l}\text { Throttle } \\
\text { Position }\end{array}$ & \multicolumn{2}{|l|}{ Load In Kgf } & $\begin{array}{l}\text { Load In } \\
\text { Newton }\end{array}$ & $\begin{array}{l}\text { Break } \\
\text { Drum } \\
\text { Speed }\end{array}$ & $\begin{array}{l}\text { Engine } \\
\text { Speed In } \\
\text { RPM }\end{array}$ & $\begin{array}{l}\text { Brake } \\
\text { Power In } \\
\text { Kw }\end{array}$ \\
\hline & & $S_{1}$ & $S_{2}$ & $S_{1}-S_{2}$ & & & & \\
\hline 1 & Idling & 0 & 0 & 0 & 0 & 212 & 700 & - \\
\hline 2 & $1 / 4$ Throttle & 25 & 3 & 22 & 220 & 455 & 1500 & 1.85 \\
\hline 3 & $1 / 2$ Throttle & 25 & 5 & 20 & 200 & 909 & 3000 & 3.4 \\
\hline 4 & $3 / 4$ Throttle & 22 & 5 & 17 & 170 & 1364 & 4500 & 4.25 \\
\hline 5 & Full Throttle & 16 & 4 & 12 & 120 & 1818 & 6000 & 4.0 \\
\hline
\end{tabular}



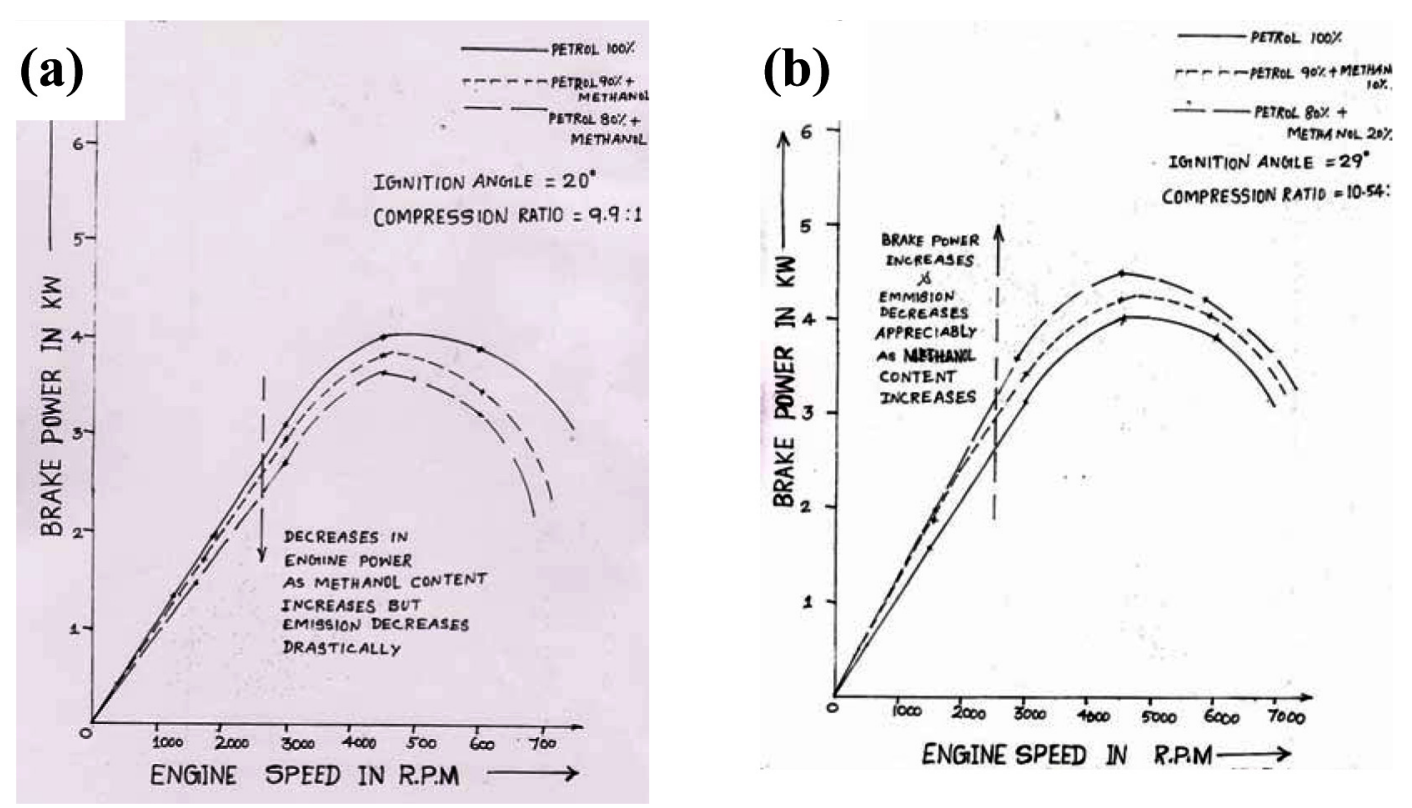

Figure 1. Engine performance analysis: (a) Before modification; (b) After modification.

\section{CASE 2}

Fuel Used: $80 \%$ Petrol + 20\% Methanol

Table 5. Power performance for $80 \%$ Petrol $+20 \%$ Methanol

\begin{tabular}{|l|l|l|l|l|l|l|l|l|}
\hline Sno & $\begin{array}{l}\text { Throttle } \\
\text { Position }\end{array}$ & \multicolumn{2}{|l|}{ Load In Kgf } & $\begin{array}{l}\text { Load In } \\
\text { Newton }\end{array}$ & $\begin{array}{l}\text { Break } \\
\text { Drum } \\
\text { Speed }\end{array}$ & $\begin{array}{l}\text { Engine } \\
\text { Speed In } \\
\text { RPM }\end{array}$ & $\begin{array}{l}\text { Brake } \\
\text { Power In } \\
\text { Kw }\end{array}$ \\
\hline & & $\mathrm{S}_{1}$ & $\mathrm{~S}_{\mathbf{2}}$ & $\mathrm{S}_{\mathbf{1}}-\mathrm{S}_{\mathbf{2}}$ & & & & \\
\hline 1 & Idling & 0 & 0 & 0 & 0 & 230 & 759 & - \\
\hline 2 & $1 / 4$ Throttle & 25 & 2 & 23 & 230 & 455 & 1500 & 1.92 \\
\hline 3 & $1 / 2$ Throttle & 25 & 2.5 & 22.5 & 225 & 909 & 3000 & 3.75 \\
\hline 4 & $3 / 4$ Throttle & 22 & 5 & 18 & 180 & 1364 & 4500 & 4.25 \\
\hline 5 & Full Throttle & 18 & 5 & 13 & 130 & 1818 & 6000 & 4.2 \\
\hline
\end{tabular}

The values of brake power from the above tabulations are plotted against RPM in the following graphs given in Figure 1. to analyse the results.

\section{Conclusion}

From all the above works, we can come to a conclusion that as the percentage of alcohol increases, performance of engine tends to decrease generally. However after doing engine modifications such as increasing the engine compression ratio and advancing the ignition timing the engine performance increases, almost $12.5 \%$ increase in the power output is achieved in this project.

\section{References}

1. Shenghua L, Clemente E R C et al. (2007). Study of spark ignition engine fueled with methanol/gasoline fuel blends, Applied Thermal Engineering, vol 27(11-12), 19041910.

2. Ganesan (2008). Internal Combustion Engines, Tata McGrawHill Education Pvt Ltd, India.

3. Mathur, and Sharma (2010). Internal Combustion Engines, Dhanpat Rai Publishers, India.

4. Shenghua L, and Hui L (2008). Effects of methanol - gasoline blend on SI engine performance and emissions, Energy and Fuels, vol 22(2), 1254-1259. 